\title{
THE NATURAL RESOURCES POTENCY OF MARINE ECOTOURISM AS AN ENVIRONMENTAL EDUCATION SOURCE
}

\author{
Dian ASWITA* \\ Universitas Serambi Mekkah, Faculty of Teacher Training and Education, Aceh, Indonesia, e-mail: aswita_dian@yahoo.com
}

I Gusti Putu SURYADARMA

Yogyakarta State University, Biology Education, Yogyakarta, Indonesia, e-mail: suryadarma @uny.ac.id

Slamet SUYANTO

Yogyakarta State University, Biology Education, Yogyakarta, Indonesia, e-mail: slamet_suyanto@uny.ac.id

Tutut HERAWAN

AMCS Research Center, Yogyakarta, Indonesia, e-mail: tutut@idu.ac.id

\begin{abstract}
Citation: Aswita, D., Suryadarma, I.G.P., Suyanto, S., \& Herawan, T. (2020). THE NATURAL RESOURCES POTENCY OF MARINE ECOTOURISM AS AN ENVIRONMENTAL EDUCATION SOURCE. GeoJournal of Tourism and Geosites, 31(3), 996-1003. https://doi.org/10.30892/gtg.31310-533
\end{abstract}

\begin{abstract}
Sabang Island is one of the atolls (coral) islands in Aceh and has a diverse biodiversity. Coral reef ecosystems are the main ecosystem in coastal and marine areas, where in addition to having ecological values, the marine natural resources also have promising economic value to the community in the field of tourism. Tourism can provide context for learning experiences, can be integrated into environmental education programs, and can be used as a source of learning to increase a learner's awareness and concern for the environment and it is also committed to preventing environmental damage. This research used a survey method on data collection of coral observation surveys used Line Intercept Transect (English et al., 1997; Hill and Wilkinson, 2004) with a length of 100 meters 4 Segment, while observing fish species used Fish Belt Transect. The data obtained were counted and tabulated in table form, then biological biodiversity analysis is carried out (Mueller-Dombois and Ellenberf, 1974; Ludwig and Reynold, 1988; Odum, 1971). The results from natural resource potency analysis for marine ecotourism is concluded that the natural resource potency for marine ecotourism was very varied and could be used as a learning resource for environmental education categorized into two, namely physical and non-physical environments. Direct learning activities in the real environment through environmental education are expected to develop basic knowledge about the environment, be a guide in interacting with the environment, improve reasoning and identifying problem skills, contribute to problem solving, and prevent new problems. Utilization of nat ural resources for marine ecotourism as a source of environmental education is learning resources by utilization.
\end{abstract}

Key words: ecotourism, environmental education, learning resources, natural resources

$* \quad * \quad * \quad * \quad * \quad *$

\section{INTRODUCTION}

Indonesia is an archipelago that has a unique and diverse mega-biodiversity. Aceh as one of the westernmost provinces in Indonesia also has such abundant biodiversity. Many studies have been carried out to find and map the natural resource potency in Aceh, especially in the coastal and marine areas of Aceh. Sabang Island is one of the atoll islands (coral islands) in Aceh. The coral families that can be found in the sea of Sabang Island are Acroporidae, Pocilloporidae, Faviidae, Dendrophylliidae, Poritidae, Trachyphylliidae, Mussidae, Caryophylliidae, Pectiniidae, Astrocoeniidae, Oculinidae, Agariciidae, Fungiidae, Merulinidae, Helioporidae, Milleporidae and Siderastreidae (Utama and Budiyanto, 2017; Aswita et al., 2015; Nasir, 2007). In addition, Kamal et al. (2015) state that the coral diversity index in the Litoral Zone of Iboih Waters in Sabang is high ( $\mathrm{H} '=3.28$ ) with the composition of coral genus in the litoral zone of Iboih waters consisting of Acropora, Montipora, Coeloseris, Gardineroseris, Stylocoeniella, Euphyllia, Cyphastrea, Favites, Goniastrea, Leptastrea, Leptoria, Platygyra, Ctenactis, Cycloseris, Heliopora, Hydnophora, Acanthastrea, Galaxea, Pectinia, Pocillopora, Goniopora, Porites, Psammocora, and Pseudosiderastrea.

Coral reefs are dynamic ecosystems with high biodiversity and productivity. Various types of marine biota use of coral reefs as their home. Few families of coral reef fish that can be found are Pomacentridae, Acanthuridae, Labridae, Pomacanthidae, Tetraodontidae, Aulostomidae, Balistidae, Caesionidae, Muraenidae, Serranidae, Chaetodontidae, Scaridae, Lethrinidae, Apogonidae, Ostraciidae, Pinguipedidae, Mullidae, Scorpaenidae, Holocentridae, Nemipteridae, Dasyatidae and Zanclidae (Aswita et al., 2015; Hastuty et al., 2014 Fadli et al., 2012; Rudi and Fadli, 2012; Rudi et al., 2009). The whole organism forms a very beautiful unit on the sea floor and has ecological value for the universe. In addition to having ecological values, marine natural resources also have economic value. One of the promising utilizations of marine natural resources is in the field of tourism. The marine natural resource potency is used as a natural tourist attraction with various activities that attract tourists. It is used as a tourist attraction on Sabang Island as presented in Table 1.

These tourism potencies not only function as a place to visit in a series of tourist activities, become a source of economic income for local people, and increase local revenue, but they are also placing for social interaction and cultural exchange. Besides, the marine tourism object (ecotourism) can also be used as a learning resource and able to provide direct learning experiences to students so th at they can easily construct understanding of concepts and experiences that have been previously owned. Several previous studies have also reported the same thing, that tourism can provide a context for the learning experience (Bos et al., 2013); ecological tourism which is integrated into environmental education programs or programs that offer students experience and apply learning opportunities, greatly influences or changes their feelings and perceptions about the environment (Niesenbaum and Barbara, 2001); tourist sites that are used as a source of learning can 
realize the sharing of information, knowledge, experience, and skills when the teaching and learning process takes place (Bhuiyan et al., 2010; Setiyono et al., 2012; Rahayu et al., 2015). The use of the environment and marine natural resources as a source of learning can be an alternative in environmental education to support the realization of environmental conservation. Pedrini et al. (2015), stated that the development of many environmental education and ecotourism programs in the local marine environment is very important to preserve coastal ecosystems. Russell (1994) states that learning experiences in nature are considered to lead to an understanding and commitment to conservation. Furthermore, Beaumont (2001) mentions that ecotourism has the ability to increase participants' knowledge or understanding of nature, and motivation to do ecotourism can also explain their tendency to learn from experience.

Table 1. Marine Nature Tourism Potency in Sabang City

(Data Source: Dinas Pariwisata dan Kebudayaan Kota Sabang (2016); Sabang Administration Map (Aswita et al., 2018)

\begin{tabular}{|c|c|c|c|}
\hline No & Sea and Coastal Tourism Destinations & No & Diving Spots \\
\hline 1 & Teupin Cirik Beach & 1 & Lhok Iboih \\
\hline 2 & Lhong Krueng Raya Beach & 2 & The Canyon \\
\hline 3 & Teupin Tongkang Beach & 3 & Batee Gla \\
\hline 4 & Sumur Tiga Beach & 4 & Batee Tokong \\
\hline 5 & Tapak Gajah Beach & 5 & Seulako Drift \\
\hline 6 & Jaboi Beach & 6 & Arus Balee \\
\hline 7 & Gua Sarang & 7 & Rubiah Utara \\
\hline 8 & Beurawang Beach & 8 & Rubiah Sea Garden \\
\hline 9 & Pasir Putih Beach & 9 & Batee Meuronron \\
\hline 10 & Pasir Teungoh Beach & 10 & Batee Dua Gapang \\
\hline 11 & Ujong Kareung Beach & 11 & Limbo Dua Gapang \\
\hline 12 & Teupin Reudep Beach/Batee Gajah Beach & 12 & Under Water Vulcano \\
\hline 13 & Arun Beach & 13 & Wreck Sophie Rickmers \\
\hline 14 & Klah Island & 14 & Lhok Pasiran \\
\hline 15 & Serui Beach & 15 & Sumur Tiga \\
\hline 16 & Pria Laot Beach & 16 & Anoi Itam \\
\hline 17 & Waterfall Pria laot & 17 & Lhong Angen \\
\hline 18 & Keunekai Beach & 18 & Pante Peunateung \\
\hline 19 & Gapang Beach & & \\
\hline 20 & Calok Meunasah (Radar) Beach & & \\
\hline 21 & Teupin Layeu Iboih Beach & & \\
\hline 22 & Teupin Serkui Beach & & \\
\hline 23 & Teupin Reudup Beach & & \\
\hline 24 & Rubiah Island & & \\
\hline 25 & Sea World of Rubiah Island & & \\
\hline 26 & Teupin Bube Beach & & \\
\hline
\end{tabular}

Utilization of the learning environment in this study can be categorized as learning resources by utilization (Rohani and Ahmadi, 1995), namely by utilizing tourist sites with the concept of ecotourism and environmental education (ecology), where the objectives to be achieved are to increase environmental knowledge and encourage attitudes and behaviors pro-environment (Wanga et al., 2013; Sander, 2012), and the expected ultimate goal is the sustainability of life (natural environment and ecosystems) (Bhuiyan et al., 2010).

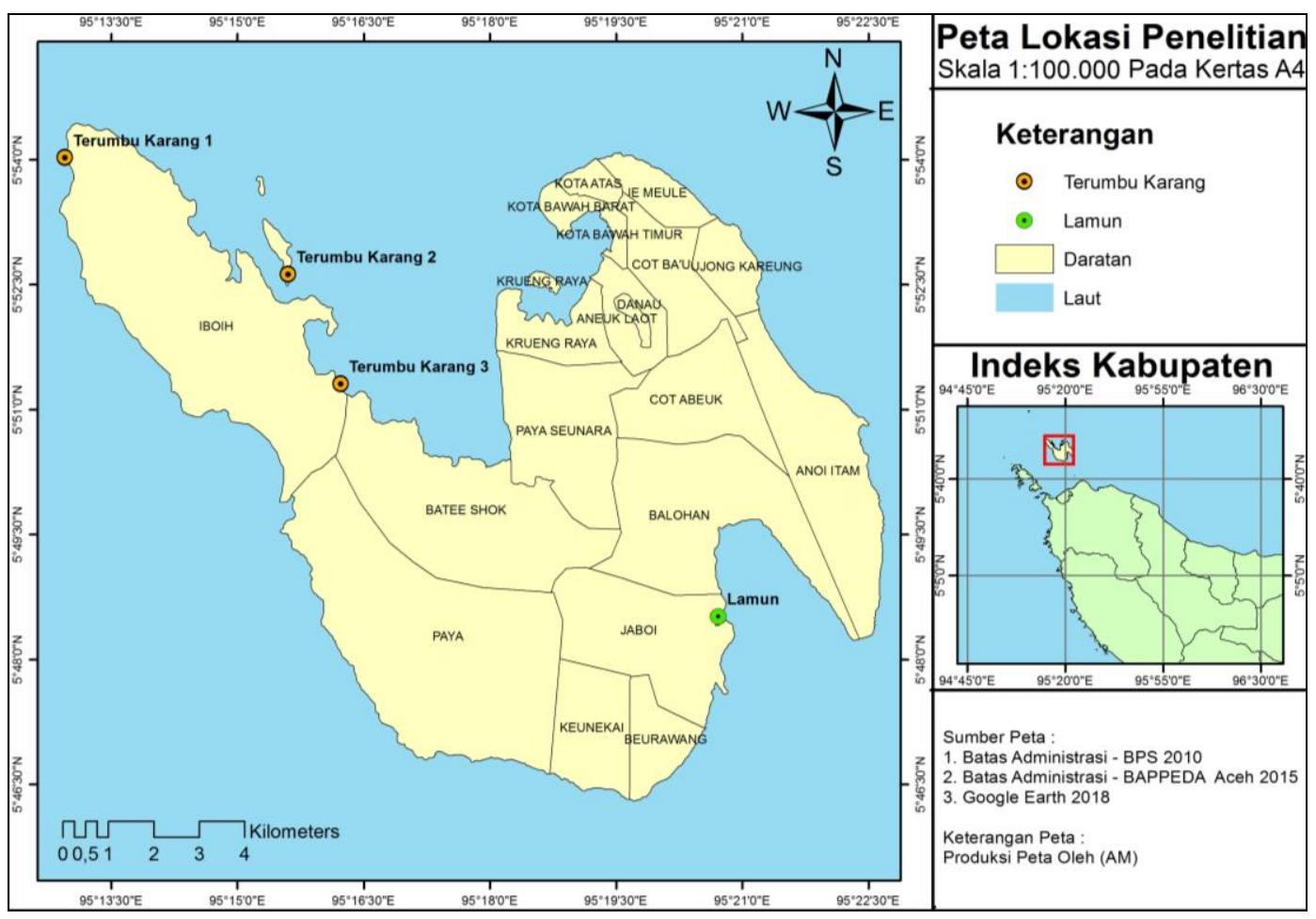

Figure 1. Administrative Map of the Research Location (Source: Research Data, 2018) Description: Terumbu Karang 1 is in Canyon Location; Terumbu Karang 2 is in Sea Garden Rubiah Location; Terumbu Karang 3 is in Limbo Dua Gapang Location 
The aim of environmental education is to develop humans' awareness and concern for the environment and its related problems. It is also expected to raise their knowledge, skills, attitudes, motivations, and commitment to work individually and collectively in finding solutions to current existing environmental problems and prevent new problems (Texas Natural Resource / Environmental Literacy Plan, 2017). Because many factors can cause damage to marine natural resources, in addition to the consequences of natural factors and disasters, the use of marine natural resources as a function of fisheries and excessive tourism can also have a negative impact on the environment. Hence, it takes an effort to use the environment with the intention to make people aware of the importance of caring for the environment and the marine natural resources. Thus, the utilization of marine ecotourism objects as a learning resource for environmental education can be considered to support the experience and process of education that helps individuals gain knowledge and skills to make decisions and take actions that are responsible for natural and environmental resources and their sustainability for future generations. Therefore, this paper determines the form of the utilization of natural resource of marine ecotourism potency as a source of environmental education.

The rest of this paper is organized as follow: Section 2 presents proposed method. Section 3 presents the obtained results and following by discussion. Finally Section 4 concludes this work.

\section{MATERIALS AND METHODS}

This research used a survey method on data collection of coral observation surveys used Line Intercept Transect (English et al., 1997; Hill and Wilkinson, 2004) with a length of 100 meters 4 Segment, while observing fish species used Fish Belt Transect.

This research was conducted from March to May 2018 at three marine tourism destinations on Sabang Island namely Canyon, Sea Garden Rubiah and Limbo Dua Gapang (Figure 1). The tools used for observation and documentation of activities included underwater cameras, roller meters, coral reef identification keys, GPS, scuba diving equipment, and snorkeling equipment.

The data obtained were counted and tabulated in table form. Analysis of biological biodiversity by the formulas shown in Table 2 . (Mueller-Dombois and Ellenberf, 1974; Ludwig and Reynold, 1988; Odum, 1971).

Table 2. The Formula Used for Quantitative Descriptive Analysis

\begin{tabular}{|c|c|c|}
\hline Formula & Formula Description & Indicators \\
\hline $\begin{array}{l}\text { Percentage of coral reef cover (English et al., 1997) } \\
n i=\frac{l i}{L} \times 100 \%\end{array}$ & $\begin{array}{l}n i=\text { Percentage of live coral cover }(\%) \\
l i=\text { The length of each live coral } \\
\quad \text { lifeform }(\mathrm{cm}) \\
L=\text { Total length of line transect }(\mathrm{cm})\end{array}$ & $\begin{array}{l}\text { If the cover ranges from: } \\
0 \%-24,9 \%=\text { Bad } \\
25 \%-49,9 \%=\text { Moderate } \\
50 \%-74,9 \%=\text { Good } \\
75 \%-100 \%=\text { Very Good }\end{array}$ \\
\hline $\begin{array}{l}\text { Shannon-Wiener diversity index (Ludwig and } \\
\text { Reynold, 1988) } \\
H^{\prime}=-\sum_{i-1}^{s}(p i) \operatorname{Ln} p i\end{array}$ & $\begin{array}{l}H^{\prime}=\text { Shannon-Wiener diversity index } \\
P i=n i / N \\
n i=\text { Total number of individuals in a species } i \\
N=\text { Total number of individuals for all species }\end{array}$ & $\begin{array}{l}\text { If } H^{\prime}>3 \text {. so the diversity is high } \\
\text { If } 1<H^{\prime}<3 \text {. so the diversity is moderate } \\
\text { If } H^{\prime}<1 \text {. so the diversity is low }\end{array}$ \\
\hline $\begin{array}{l}H^{s} \\
\text { Unifermity Index (Odum, 1971) } \\
E=H \text { max } \\
\text { In which, } H \text { max }=\operatorname{In} S\end{array}$ & $\begin{array}{l}E=\text { Uniformity Index } \\
H^{\prime}=\text { Diversity Index } \\
S=\text { The number of Species }\end{array}$ & $\begin{array}{l}\text { If: } \\
e<0.4=\text { The uniformity is low } \\
0.4<e<0.6=\text { The uniformity is moderate } \\
e>0.6=\text { The uniformity is high }\end{array}$ \\
\hline $\begin{array}{l}\text { Simpson's Dominance Index (Odum, 1971) } \\
D=\sum P i^{2}\end{array}$ & $\begin{array}{l}D=\text { Dominance Index } \\
\sum P i^{2}=\text { The proportion square of the first species }\end{array}$ & $\begin{array}{l}\text { The dominance index criteria are as follows: } \\
D>0.5=\text { dominance exists } \\
D<0.5=\text { dominance does not exist }\end{array}$ \\
\hline
\end{tabular}

\section{RESULTS DISCUSSIONS}

\section{The Natural Resource Potency of Marine Ecotourism}

Based on the survey results of the coral reef ecosystems in three marine ecotourism locations, namely Canyon, Limbo Dua Gapang, and Sea Garden Rubiah, especially observations on coral and reef fish, it can be known that the natural resource potency of each tourism destination varies. In the Canyon tourist location, five coral genus (Figure 2) were found with a diversity index value of $H^{\prime}=2.263$ which was categorized as a moderate level for the diversity of the coral species. Different things could be seen in the Limbo Dua Gapang tourism destination where it was found that there were nine coral genus with a diversity index of $H^{\prime}=2.434$ which were categorized as moderate diversity. Besides that, even though the diversity index of coral species is moderate, namely $H '=1.146$, at the tourism destination Sea Garden Rubiah, there were only found five genus.

Table 3. Coral Reefs in the Marine Ecotourism Area of Sabang Island (Source: Research Data, 2018)

\begin{tabular}{|c|c|c|c|c|c|c|c|c|c|c|c|c|}
\hline \multirow{2}{*}{ Genus } & \multicolumn{4}{|c|}{ Canyon } & \multicolumn{4}{|c|}{ Limbo Dua Gapang } & \multicolumn{4}{|c|}{ Sea Garden Rubiah } \\
\hline & Viewed & $H^{\prime}$ & $\boldsymbol{E}$ & $D$ & Viewed & $H^{\prime}$ & $E$ & $D$ & Viewed & $H^{\prime}$ & $E$ & $D$ \\
\hline Acropora & + & \multirow{12}{*}{2.263} & \multirow{12}{*}{0.310} & \multirow{12}{*}{0.218} & + & \multirow{12}{*}{2.434} & \multirow{12}{*}{0.334} & \multirow{12}{*}{0.278} & + & \multirow{12}{*}{1.146} & \multirow{12}{*}{0.214} & \multirow{12}{*}{0.020} \\
\hline Echinopora & + & & & & - & & & & - & & & \\
\hline Montipora & + & & & & + & & & & - & & & \\
\hline Pocillopora & + & & & & + & & & & $\overline{-}$ & & & \\
\hline Tubastrea & + & & & & - & & & & - & & & \\
\hline Coscinaraea & - & & & & + & & & & + & & & \\
\hline Fungia & - & & & & + & & & & + & & & \\
\hline Galaxea & - & & & & + & & & & - & & & \\
\hline Goniopora & - & & & & + & & & & - & & & \\
\hline Platygyra & - & & & & + & & & & - & & & \\
\hline Porites & - & & & & + & & & & + & & & \\
\hline Pavona & - & & & & - & & & & + & & & \\
\hline
\end{tabular}

Other results of the analysis revealed (Table 3) that the entire coral community in three marine ecotourism locations showed that the small coral uniformity index and the species were depressed with $E=0.310$ for the Canyon area, $E=0.334$ for the Limbo Dua Gapang area, and $E=0.214$ for the Sea Garden Rubiah area. Meanwhile, for the dominance index, it was known that the dominance of the coral genus in the three ecotourism locations was low, in the sense that there was no dominance between one species and the others, with a $\mathrm{D}=0.218$ for the Canyon area, $\mathrm{D}=0.278$ for the Limbo Dua Gapang area, and D $=0.020$ for Sea Garden Rubiah. 


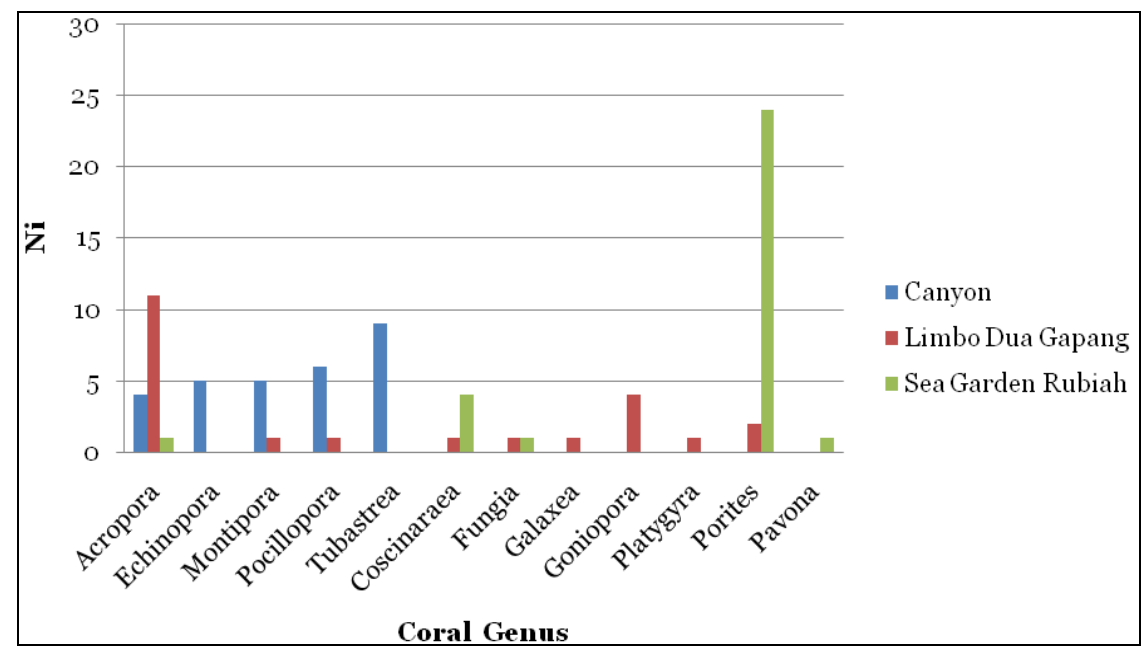

Figure 2. Presence of Coral Reefs in the Marine Ecotourism Area of Sabang Island (Source: Research Data, 2018)

Based on the observations it is known that at the location of the Sea Garden Rubiah, were found 5 genera of corals, where the number of corals of the genus Porites found the most (Figure 2). In the Limbo Dua Gapang location which is the most found location of the coral genus compared to other locations, namely 9 genus corals, with the highest number of corals being from the genus Acropora. Whereas in the Canyon area, 5 coral genera were found, with the most found in the genus Tubastrea. The Acropora genus is a coral that is found and seen alive at the three tourist sites, while the Genus Porites is the genus with the most numbers found.

In general, the basic conditions of the waters in the three marine ecotourism locations were covered with coral, rubble, sand and rocks (Table 4). This rubble could be caused by several factors including human activities such as tourist footrests, fishing activities, fish hunting, and due to being hit by ship anchors (fishing boats and tourist vessels). There were also other factors that caused the coral fractures such as weathering and natural disasters, e.g. tsunami.

Table 4. Percentage of Coral Cover in the Marine Ecotourism Area of Sabang Island (Source: Research Data, 2018)

\begin{tabular}{|c|c|c|c|c|c|c|c|c|c|}
\hline \multirow[t]{2}{*}{ Transect } & \multicolumn{3}{|c|}{ Canyon } & \multicolumn{3}{|c|}{ Limbo Dua Gapang } & \multicolumn{3}{|c|}{ Sea Garden Rubiah } \\
\hline & Life Form & Cover Length & \% Cover & Life Form & Cover Length & \% Cover & Life Form & Cover Length & \% Cover \\
\hline \multirow{5}{*}{1} & $\mathrm{CB}$ & 240 & 12 & $\mathrm{ACB}$ & 870 & 43.5 & $\mathrm{CM}$ & 1410 & 70.50 \\
\hline & CT & 270 & 13.5 & $\mathrm{CS}$ & 90 & 4,5 & $\mathrm{RC}$ & 590 & 29,50 \\
\hline & $\mathrm{RC}$ & 1390 & 69,5 & CMR & 10 & 0.5 & & & \\
\hline & $\mathrm{S}$ & 100 & 5 & RB & 695,00 & 34,75 & & & \\
\hline & & & & $\mathrm{S}$ & 335 & 16,75 & & & \\
\hline \multicolumn{2}{|c|}{ Total Cover } & \multicolumn{2}{|l|}{25,50} & & \multicolumn{2}{|l|}{48,50} & & \multicolumn{2}{|l|}{70.50} \\
\hline \multirow{8}{*}{2} & CT & 169 & 8,45 & ACB & 680.00 & 34,00 & $\mathrm{CM}$ & 714,00 & 35,70 \\
\hline & $\mathrm{CS}$ & 63 & 3.15 & $\mathrm{~S}$ & 1320 & 66,00 & $\mathrm{RC}$ & 1223.00 & 61.15 \\
\hline & $\mathrm{CE}$ & 91 & 4,55 & & & & $\mathrm{~S}$ & 63 & 3.15 \\
\hline & ACB & 50 & 2.50 & & & & & & \\
\hline & ACT & 200 & 10.00 & & & & & & \\
\hline & $\mathrm{CB}$ & 120 & 6,00 & & & & & & \\
\hline & $\mathrm{RC}$ & 1157 & 57,85 & & & & & & \\
\hline & $\mathrm{S}$ & 150 & 7,50 & & & & & & \\
\hline \multicolumn{2}{|c|}{ Total Cover } & \multicolumn{2}{|l|}{34,65} & & \multicolumn{2}{|l|}{34,00} & & \multicolumn{2}{|l|}{35,70} \\
\hline \multirow{6}{*}{3} & $\mathrm{CE}$ & 106 & 5,3 & $\mathrm{ACB}$ & 50 & 2.5 & $\mathrm{CM}$ & 656 & 32.80 \\
\hline & ACB & 20 & 1 & ACT & 40 & 2 & $\mathrm{RC}$ & 933 & 46,65 \\
\hline & $\mathrm{CS}$ & 100 & 5 & CS & 270 & 13.5 & $\mathrm{~S}$ & 411.00 & 20.55 \\
\hline & CT & 160 & 8 & CM & 140 & 7 & & & \\
\hline & $\mathrm{CB}$ & 203.00 & 10.15 & $\mathrm{~S}$ & 1500 & 75 & & & \\
\hline & $\mathrm{RC}$ & 1411.00 & 70.55 & & & & & & \\
\hline \multicolumn{2}{|c|}{ Total Cover } & \multicolumn{2}{|l|}{29,45} & & \multicolumn{2}{|l|}{25} & & \multicolumn{2}{|l|}{32.80} \\
\hline \multirow{7}{*}{4} & $\overline{\mathrm{CE}}$ & 200 & 10 & CS & 25 & 1.25 & ACB & 15,00 & 0.75 \\
\hline & $\mathrm{CS}$ & 195 & 9,75 & $\mathrm{CM}$ & 90 & 4,5 & $\mathrm{CS}$ & 150.00 & 7,50 \\
\hline & ACT & 20 & 1 & $\mathrm{RC}$ & 120 & 6 & $\mathrm{CM}$ & 1268,00 & 63.40 \\
\hline & $\mathrm{CB}$ & 215 & 10.75 & RB & 80 & 4 & CMR & 20.00 & 1.00 \\
\hline & $\mathrm{CT}$ & 215 & 10.75 & $\mathrm{~S}$ & 1685,00 & 84,25 & RB & 175,00 & 8,75 \\
\hline & $\mathrm{RC}$ & 1155 & 57,75 & & & & $\mathrm{RC}$ & 60.00 & 3.00 \\
\hline & & & & & & & $\mathrm{S}$ & 312.00 & 15,60 \\
\hline \multicolumn{2}{|c|}{ Total Cover } & \multicolumn{2}{|l|}{42.25} & & \multicolumn{2}{|l|}{5,75} & & \multicolumn{2}{|l|}{72.65} \\
\hline \multicolumn{2}{|c|}{ Description: } & & & & $\mathrm{CM}$ & & $:$ & Non Acropora $\mathrm{I}$ & assive \\
\hline $\mathrm{ACB}$ & $:$ & Acropora Branc & & & CMR & & $:$ & Non Acropora & ushroom \\
\hline ACT & $:$ & Acropora Tabul & & & CT & & $:$ & Non Acropora 1 & bipora \\
\hline $\mathrm{CB}$ & $:$ & Non Acropora B & ncing & & $\mathrm{RC}$ & & $:$ & Rock & \\
\hline $\mathrm{CE}$ & $:$ & Non Acropora $\mathrm{E}$ & crusting & & RB & & $:$ & Coral Rubble & \\
\hline $\mathrm{CS}$ & : & Non Acropora S & omassive & & $\mathrm{S}$ & & $:$ & Sand & \\
\hline
\end{tabular}

Based on the analysis in Table 4 above, it was known that coral cover in the Canyon tourism area (overall transect) ranked in the medium category. The entire transect in the Canyon tourist area was dominated by the presence of rocks, so coral cover is found between these rocks. 
Different things can be seen in the Limbo Dua Gapang tourism area where it was known that coral cover on transects 1,2 and transects 3 were in the moderate category, while that on transect 4 was in the low category. This was because on transect 4 was dominated by sand at $84.25 \%$, and coral cover found was only $5.75 \%$. In the tourist area of Sea Garden Rubiah, coral cover on transects 1 and 4 was in a good category, while coral cover on transects 2 and 3 was in the medium category. This could be seen from the high percentage of rocks and sand found on transects 2 and 3. Coral reefs are one of the main ecosystems in coastal and marine areas. However, various other marine biota could be found in the ecosystem. Coral fish make coral reefs a home for them, a place to look for food, a place to reproduce, lay eggs and spawn eggs. In other words, it can be mentioned that coral reefs are a place to live for fish and another marine biota. Analysis of reef fish diversity was also carried out in this study, and it was found that in the Canyon tourist area 21 species of fish were found from 10 families with a value of $H^{\prime}=2.98$, meaning that diversity was medium. In the Limbo Dua Gapang tourist area there were found 41 species of fish from 19 families with a value of $H^{\prime}=3.568$ meaning that the diversity was high. Meanwhile, in the tourist area of Sea Garden Rubiah, 45 species of fish were found from 16 families with a value of $H^{\prime}=3.538$ meaning that the diversity was high (Table 5).

Table 5. Coral Fish Biodiversity in the Marine Ecotourism Area of Sabang Island (Source: Research Data, 2018)

\begin{tabular}{|c|c|c|c|c|c|c|c|c|c|c|c|c|}
\hline \multirow{2}{*}{ Coral Reef Fish } & \multicolumn{4}{|c|}{ Canyon } & \multicolumn{4}{|c|}{ Limbo Dua Gapang } & \multicolumn{4}{|c|}{ Sea Garden Rubiah } \\
\hline & Found & $\mathbf{H}^{\prime}$ & $\mathbf{E}$ & D & Found & H' & $\mathbf{E}$ & D & Found & H' & $\mathbf{E}$ & D \\
\hline Acanthuridae & + & \multirow{23}{*}{2.928} & \multirow{23}{*}{0.962} & \multirow{23}{*}{0.0594} & + & \multirow{23}{*}{3.568} & \multirow{23}{*}{0.961} & \multirow{23}{*}{0.0326} & + & \multirow{23}{*}{3.538} & \multirow{23}{*}{0.929} & \multirow{23}{*}{0.0369} \\
\hline Pomachanthidae & + & & & & - & & & & + & & & \\
\hline Chaetodontidae & + & & & & + & & & & + & & & \\
\hline Pomacentridae & + & & & & + & & & & + & & & \\
\hline Labridae & + & & & & + & & & & + & & & \\
\hline Mullidae & + & & & & + & & & & + & & & \\
\hline Holocentridae & + & & & & - & & & & + & & & \\
\hline Cirrhitidae & + & & & & + & & & & - & & & \\
\hline Serranidae & + & & & & + & & & & + & & & \\
\hline Zanclidae & + & & & & + & & & & + & & & \\
\hline Centriscidae & - & & & & + & & & & - & & & \\
\hline Balistidae & - & & & & + & & & & + & & & \\
\hline Caesionidae & - & & & & + & & & & + & & & \\
\hline Scaridae & - & & & & + & & & & + & & & \\
\hline Blenniidae & - & & & & + & & & & - & & & \\
\hline Muranidae & - & & & & + & & & & - & & & \\
\hline Lethrinidae & - & & & & + & & & & - & & & \\
\hline Haemulidae & - & & & & + & & & & + & & & \\
\hline Scorpionidae & - & & & & + & & & & - & & & \\
\hline Nemipteridae & - & & & & + & & & & + & & & \\
\hline Synodontidae & - & & & & + & & & & - & & & \\
\hline Pempheridae & - & & & & - & & & & + & & & \\
\hline Priacanthidae & - & & & & - & & & & + & & & \\
\hline
\end{tabular}

Based on Table 5, it was known that coral fish species in all marine ecotourism locations tended to be stable with high uniformity, with $E=$ 0.962 for Canyon tourism area, $E=0.961$ for Limbo Dua Gapang tourist area, and $E=0.929$ for Sea Garden Rubiah. Meanwhile for species dominance it was known that species dominance was low, meaning that no species dominated other species with value $D=0.0594$ for Canyon tourism area, $C=0.0326$ for Limbo Dua Gapang tourism area, and $C=0.0369$ for Sea Garden Rubiah tourist area. Thus, it can be concluded that the natural resource potency of marine tourism in Sabang Island enormously varied and can be used as a learning resource for environmental education. The results of this study reveal that the three tourist areas, namely Canyon, Limbo Dua Gapang and Sea Garden Rubiah have the potential to become marine ecotourism locations, with the main spot being offered is the natural beauty of the underwater, namely the coral reef ecosystem. The various potentials of this natural resource, both from the group of corals, reef fish, invertebrates and other marine vertebrates, become the main attraction of marine tourism, and by changing the paradigm and applying the concept of marine ecotourism, the potential of this resource is expected to be maintained even though utilized as an object tour. The potential use of coral reef ecosystems as an ecotourism area was also revealed by Karim et al. (2019) in their study in Balikpapan Bay, Lelloltery et al. (2018) study of coral reef studies for the development of marine ecotourism in Maluku, and Johan et al. (2017) studies on the suitability of marine ecotourism in Enggano Island.

\section{Utilizing the Natural Resource Potency as a Source of Environmental Education}

The utilization of the potential of natural resources as a source of learning has been done by several previous researchers, such as what Ali et al. (2017) did in their studies in Dayang Bunting and the Tuba Islands as an educational outdoor geotourism laboratory, Reynard et al. (2018) by disseminating knowledge about geomorphological heritage by developing digital learning platforms.

The use of marine ecotourism objects in the form of coral reef ecosystems in the location of marine tourism in Sabang Island as a source of learning for environmental education was expected to open the horizons of students to better understand the symptoms and issues about environmental use (especially coral reef ecosystems) in daily life. Therefore, their awareness toward environmental sensitivity can grow, which can in turn push their active participation in maintaining and managing the environment and preventing activities that damage the environment. This is in line with constructivist learning theory. Suhendi and Purwarno (2018) mentioned that constructivist thinking is rooted in several aspects of Piaget and Vygotsky's cognitive theory. Furthermore, Nugroho and Wulandari (2017) states that constructivism theories contain a paradigm which believes that learning is an active constructive process that occurs in socio-cultural conditions. A learner is designed to be active in making changes in meaning through real activities. While the teachers are learning designers, facilitators, and motivators of students. Lowenthal and Muth (2008) states that in education, constructivism refers to the theory of knowledge and learning. These theories state that knowledge is constructed (constructed) and not received from the world or external reality. The emphasis is on the experience of a learner and not the experience of the teacher, and the construction of knowledge is done actively and not pas sively receiving information.

Furthermore, Suhendi and Purwarno (2018) stated that there are several important things in constructivist learning: (1) prioritizing real learning in relevant contexts, (2) giving priority to the process, (3) instilling learning in the context of social experience, and (4) learning is 
done to build experience. Thus, through the ecotourism approach by utilizing learning resources that are available in nature (the marine ecotourism object Canyon, Limbo Dua Gapang and Sea Garden Rubiah) will provide opportunities for students to make their own observations by conducting educational tourism activities that are integrated into the learning process. The potential biodiversity of coral reef ecosystems found in the three ecotourism locations can be utilized in ecology lecture programs (animal ecology, aquatic ecology, and other ecological fields). The concept map of ecological material that can be learned from the utilization of the potential of natural resources as a source of environmental education is shown in Figure 3.

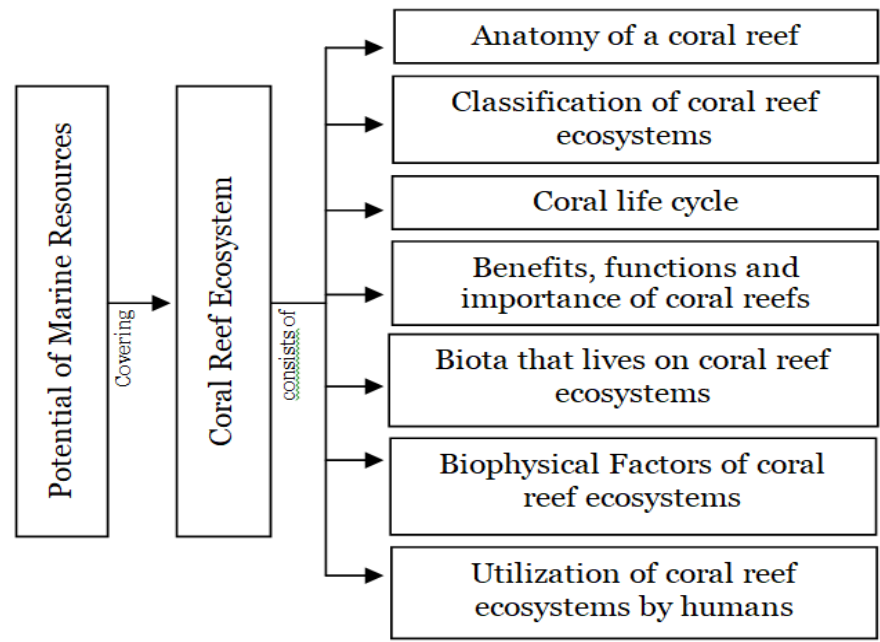

Figure 3. Concept Map of Ecological Material that can be Studied at the Three Marine Ecotourism Locations (Source: Research Data, 2018)

The purpose of utilizing the natural resource potency for marine ecotourism as a source of learning (Figure 3) is to help students get real knowledge and to understand the concepts from direct experience of the environment and the object being studied, in this case is the diversity of fauna and flora that live in coral reef ecosystems at a marine ecotourism location. The learning experience while traveling has direct implications for environmental education. Mirrahimi et al. (2011) found that natural environments have the potential to promote educational processes, personal and social development in which students can experience learning to share, to communicate, to work in a team, to increase self-awareness, self-confidence, self-regulation, self-discipline, problem solving skill, and social skills. According to those researchers, the natural environment was a source of considerable stimulation for the process of inspiring and meaningful learning. Atmodiwirjo (2013) also showed his interest in the use of the environment around the school as a learning resource about the environment.

The concept of environmental education was agreed in the Tbilisi Declaration at the Intergovernmental Conference, was convened in Tbilisi, Geogia, from October 14-26, 1977. It states that "Environmental education is a process that aim s to develop a world population that is aware and caring for the environment and its problems, has the attitude, motivation, knowledge, commitment and skills to work individually and collectively towards solutions to problems and prevention of new problems", the concepts of environmental education are knowledge, awareness, attitudes, skills and participation (UNESCO, 1978; UNESCO and UNEP, 1978). Based on the concept of environmental education, the form of utilization of the natural resource potency for marine ecotourism on Sabang Island can be presented in Table 6.

Table 6. Study of Natural Resource Potency for Marine Ecotourism in Sabang Island as a Source of Environmental Education

\begin{tabular}{|c|c|c|c|}
\hline Concept EE & Expected Objectives & Teaching and Learning Activities & Ecotourism Activities \\
\hline Knowledge & $\begin{array}{l}\text { To help individuals, groups, and } \\
\text { communities gain a variety of } \\
\text { experiences and a basic understanding } \\
\text { of what is needed to create and } \\
\text { maintain a sustainable environment }\end{array}$ & $\begin{array}{l}\text { 1. Observe various marine biota (coral reefs, fish, marine invertebrates, } \\
\text { and flora that live in the sea), both from species diversity, dominance, } \\
\text { coral lifeform, interaction patterns and also the distribution of these } \\
\text { biota, and damage to coral reefs. } \\
\text { 2. Knowing physical factors and water quality (water salinity, water } \\
\text { temperature, and water } \mathrm{pH} \text { ). }\end{array}$ & \multirow{5}{*}{$\begin{array}{l}\text { 1. Scuba Diving } \\
\text { 2. Snorkeling } \\
\text { 3. Photography } \\
\text { Underwater } \\
\text { 4. Swimming } \\
\text { 5. Bottom Glass } \\
\text { Boating } \\
\text { 6. Coral Reef } \\
\text { Conservation } \\
\text { Tourism } \\
\text { 7. Coral } \\
\text { Transplantation } \\
\text { Tourism } \\
\text { 8. Culinary Tourism } \\
\text { and Recreation } \\
\text { 9. Play Jet Sky } \\
\text { (Aswita, 2018) }\end{array}$} \\
\hline Awareness & $\begin{array}{l}\text { To help individuals, groups and } \\
\text { communities gain awareness and } \\
\text { sensitivity to the environment as a } \\
\text { whole and to questions and } \\
\text { problems related to environment } \\
\text { and development }\end{array}$ & $\begin{array}{l}\text { 1. Know about the responsible behavior when entering the habitat of an } \\
\text { organism such as not taking or removing the organism from its } \\
\text { habitat, and not stepping on coral reefs. } \\
\text { 2. Be aware of wanting to pick up and clean up the rubbish found around } \\
\text { it and throw it away in the space provided. } \\
\text { 3. Be aware of good behavior so that its presence does not pose a threat } \\
\text { to certain habitats. }\end{array}$ & \\
\hline Attitude & $\begin{array}{l}\text { To help everyone, group and } \\
\text { community obtain a range of values } \\
\text { and feelings of concern for the } \\
\text { environment and motivation to actively } \\
\text { participate in environmental protection }\end{array}$ & $\begin{array}{l}\text { 1. Do not remove the organism from its habitat } \\
\text { 2. Do not step on coral reefs } \\
\text { 3. Do not dispose garbage to the sea, drainage, or other prohibited place } \\
\text { 4. Do not catch / disturb animals around it. }\end{array}$ & \\
\hline Skills & $\begin{array}{l}\text { To help individuals, groups, and } \\
\text { communities acquire skills to } \\
\text { identify, anticipate, prevent and } \\
\text { solve environmental problems }\end{array}$ & $\begin{array}{l}\text { 1. Educate to shape the students' behavior sensitive to the environment, } \\
\text { one of which is through scuba diving training, so that they can control } \\
\text { itself and minimize contact between divers and sensitive marine life } \\
\text { (Cater and Cater, 2007). }\end{array}$ & \\
\hline Participation & $\begin{array}{l}\text { To provide opportunities for } \\
\text { individuals, groups, and } \\
\text { communities to have the } \\
\text { opportunity and motivation to be } \\
\text { actively involved at all levels in } \\
\text { creating a sustainable environment. }\end{array}$ & $\begin{array}{l}\text { 1. Participate actively in conservation tourism, so that students can } \\
\text { experience by themselves how to conserve coral reefs through coral } \\
\text { reef transplantation activities. Conservation activities can also be done } \\
\text { on several types of reef fish. } \\
\text { 2. Participate in tourism actions such as the cleaning-up of underwater } \\
\text { beach, where everyone will be invited to snorkel or scuba dive with } \\
\text { the aim of cleaning the environment from rubbish. }\end{array}$ & \\
\hline
\end{tabular}


The learning process about environmental education carried out using the natural resource potency for marine ecotourism (Table 6) shows that the education process is a process that occurs directly and continues to run throughout life. Pitman et al. (2010), states that "experience, exploring, and finding are key descriptors of learning experiences". Furthermore, personal experience and the process of investigating the environment formed over tourism activities enable the creation of critical awareness and concern for the environment. In other words, it can be stated that skills, knowledge, and understanding can be obtained through direct experience and learning processes in nature. Kostova and Atasoy (2008) state that case studies and conducting ecological investigations can develop students' thinking abilities. Gilchrist et al. (2016) mention that fieldwork has a positive impact on long-term memory, leading to individual growth and increased social skills, strengthening the relationship between affective and cognitive, which provides a bridge for higher level learning. Moreover, adventure learning can have a positive impact on self-confidence, self-esteem, communication skills and the ability to work in teams.

Environmental education through the direct learning process in nature aims to increase students' knowledge and positive attitudes towards the environment, offering opportunities to connect and apply the learning that has been gained in direct life in the real world. Erhabor and Don (2016) reveal that environmental education programs have a strong influence on environmental knowledge and positive attitudes towards the environment. Abd El-Salam et al. (2009), also report that environmental education programs are known to increase knowledge and positive attitudes towards the environment. There is a positive correlation between attitude and level of knowledge of a person before and after participating in an environmental education program. Padrão and Tavares (2014) state that environmental education aims to guide and determine a sustainable, committed social future, forming a community that is aware and responsible for the environment, not only for their generation but also for future generations.

\section{CONCLUSION}

The marine ecotourism resource potencies that have been successfully mapped in this study can be stated to be very diverse and varied, and can be used as a learning resource for environmental education, which can be categorized into two, namely (1) physical environment including coral reef ecosystems, recognizing biotic and abiotic components, getting to know various types of coral and reef fish as well as the presence or absence of environmental pollution due to human activities and (2) non-physical environment, in the form of living systems of these aquatic biota, namely interactions between living things in coral reef ecosystems, coral life cycles, breeding of reef fish, and the system of customs of the local community in relation to environmental attitudes and behavior (local wisdom related to environmental utilization and management).

Direct learning activities in the real environment are expected to provide meaningful learning, so as to develop a person's basic knowledge about environmental functions, how to interact with the environment, improve reasoning skills about environmental issues and problems related to the use of the environment as a tourist attraction, as well as the improvement of skills in identifying problems, contributing to solving environmental problems, and preventing new problems. This is in line with constructivist learning theory, Suhendi and Purwarno (2018) mentioned that a person can be said to learn when they can construct their own meaning through learning experiences.

\section{Aknowlegments}

The author would like to say thank to the researchers from the Ocean Diving Club at Syiah Kuala University and the Gampong Iboih community, so this research can be done well.

\section{REFERENCES}

Abd El-Salam, M.M., El-Naggar, H.M., \& Hussein, R.A. (2009). Environmental education and its effect on the knowledge and attitudes of preparatory school students. Journal of Egypt Public Health Association, 84(3-4), 345-69.

Ali, C.A., Zawri, N.F., Simon, N., \& Mohamed, K.R. (2017). Limestone-granite contact zone in the dayang bunting \& tuba islands, Malaysia: An educational outdoor geotourism laboratory. GeoJournal of Tourism and Geosites, 19(1), 50-60.

Aswita, D. (2018). Ekowisata Pesisir dan Laut: Biodiversitas SDA, Pemanfaatan dan Pengelolaannya, [Coastal and marine ecotourism: Natural resource biodiversity, utilization and management], K-Media, Yogyakarta.

Aswita, D., Sarong, M.A., \& Sugianto, S. (2015). Early study of aquatic biodiversity in teupin layeu iboih sabang for marine ecotourism. Jurnal Ilmiah Peuradeun, 3(2), 381-390.

Aswita, D., Suryadarma, I.G.P., \& Suyanto, S. (2018). Local wisdom of Sabang Island society (Aceh, Indonesia) in building ecological intelligence to support sustainable tourism. GeoJournal of Tourism and Geosites, 22(2), 393-402. https://doi.org/10.30892/gtg.22210-297

Atmodiwirjo, P. (2013). School ground as environmental learning resources: Teachers' and pupils' perspectives on its potentials, uses and accessibility. International Electronic Journal of Environmental Education, 3(2), 101-119.

Beaumont, N. (2001). Ecotourism and the conservation ethic: Recruiting the uninitiated or preaching to the converted? Journal of Sustainable Tourism, 9(4), 317-341. https://doi.org/10.1080/09669580108667405

Bhuiyan, Md.A.H., Siwar, C., \& Islam, R. (2010). Ecotourism and environmental education: An opportunity for Bangladesh. Proceedings of International Conference on Environmental Aspects of Bangladesh (ICEAB10), Japan, Sept. 2010, pp. 43-44.

Bos, L., McCabe, S., \& Johnson, S. (2013). Learning never goes on holiday: an exploration of social tourism as a context for experiential learning. Current Issues in Tourism, 18, 859-875. https://doi.org/10.1080/13683500.2013.790878

Cater, C., \& Cater, E. (2007). Marine ecotourism: Between the devil and the deep blue sea, CABI Publishing, Wallingford. https://doi.org/10. $1079 / 9781845932596.0000$

English, S., Wilkinson, C., \& Baker, V. (1997). Survey manual for tropical marine resources, Australian Institute of Marine Science, Townsville.

Erhabor, N.I., \& Don, J.U. (2016). Impact of environmental education on the knowledge and attitude of students towards the environment. International Journal of Environmental \& Science Education, 11(12), 5367-5375.

Fadli, N., Aidia, M., \& Rudi, E. (2012). Composition of coral reef fishes in coral transplantation location in Rubiah Island, Sabang City, Aceh. Depik, 1(3), 196-199.

Gilchrist, M., Passy, R., Waite, S., \& Cook, R. (2016). Exploring schools' use of natural spaces, in Freeman, C. \& Tranter, P. (eds) Risk, Protection, Provision and Policy, Vol. 12 of Skelton, T. (ed) Geographies of Children and Young People, Springer, Singapore. https://doi.org/10.1007/978-981-287-035-3_18

Hastuty, R., Yonvitner., \& Adrianto, L. (2014). Coral cover and composition of reef fishes inside and outside of marine protected areas, eastern coast of Weh Island, Sabang. Depik, 3(2), 99-107. https://doi.org/10.13170/depik.3.2.1468

Hill, J., \& Wilkinson, C. (2004). Methods for ecological monitoring of coral reefs, Australian Institute of Marine Science, Townsville.

Johan, Y., Yulianda, F., Kurnia, R., \& Muchsin, I. (2017). Analysis of marine ecotourism suitability for diving and snorkeling activities in Enggano Island. International Journal of Sciences: Basic and Applied Research (IJSBAR), 36(6), 202-212.

Kamal, S., Mahdi, N., \& Humaira. (2015). Keanekaragaman Karang di Zona Litoral Perairan Iboih Kecamatan Sukakarya Kota Sabang [Coral diversity in the litoral zone of Iboih waters, Sukakarya District, Sabang City]. Jurnal Biotik, 3(1), 45-56 (In Indonesian). https://doi.org/10.22373/biotik.v3i1.991 
Karim, S., Kusuma, B.J., \& Mahfud, T. (2019). Application the development Of Balikpapan Bay based on sustainable tourism. GeoJournal of Tourism and Geosites, 24(1), 29-38. https://doi.org/10.30892/gtg.24103-340

Kostova, Z., \& Atasoy, E. (2008). Methods of successful learning in environmental education. Journal of Theory and Practice in Education, 4 (1), $49-78$.

Lelloltery, H., Pudyatmoko, S., Fandelli, C., \& Baiquni, M. (2018). Study of coral reef for marine ecotourism development based on region suitability and carrying capacity in Marsegu Island Nature Tourism Park, Maluku, Indonesia. Biodiversitas, 19(3), 1089-1096. https://doi.org/10.13057/biodiv/d190342

Lowenthal, P., \& Muth, R. (2008). Constructivism. In E. F. Provenzo, Jr. (Ed.), Encyclopedia of the social and cultural foundations of education, Sage, Thousand Oaks, CA.

Ludwig, J.A., \& Reynolds, J.F. (1988). Statistical ecology, Jhon Wiley \& Sons, Newyork.

Mirrahimi, S., Tawil, N.M., Abdullah, N.A.G., Surat, M., \& Usman, I.M.S. (2011). Developing conducive sustainable outdoor learning: The impact of natural environment on learning, social and emotional intelligence. Procedia Engineering, 20, 389-396. https://doi.org/10.1016/j.proeng.2011.11.181

Mueller-Dombois, D., \& Ellenberg, H. (1974). Aims and methods of vegetation ecology, Jhon Wiley \& Sons, Newyork.

Nasir, M. (2007). Community-driven coral conservation in Aceh, Indonesia. Final Report, August 2007, A Report to Rufford Small Grant (for Nature Conservation), Faculty of Mathematic and Natural Science, University of Syiah Kuala, Banda Aceh.

Niesenbaum, R.A., \& Barbara, G. (2001). Community-based eco-education: Sound ecology and effective education. The Journal of Environmental Education, 3(1), 12-16. https://doi.org/10.1080/00958960109600796

Nugroho, K.Y., \& Wulandari, D.F. (2017). Constructivist learning paradigm as the basis on learning model development. Journal of Education and Learning, 409(4), 410-415. https://doi.org/10.11591/edulearn.v11i4.6852

Odum, E.P. (1971). Fundamental of ecology. 3rd ed. Tokyo, W. B. Saundes Company, Japan.

Padrão, J., \& Tavares, J. (2014). Environmental education and tourism. Mediterranean Journal of Social Sciences, 5(22), 540-544. https://doi.org/10.5901/ mjss.2014.v5n22p540

Pedrini, A.G., Brotto, D.S., Ghilardi-Lopes, N.P., Lopes, M.C., \& Ferreira, L.P. (2015). Environmental Education and ecotourism concepts in Marine Protected Area of Armação de Búzios, Rio de Janeiro, Brazil: reflections for the adoption of coastal ecotourism. Revista Brasileira de Ecoturismo, São Paulo, 8(1), 59-73. https://doi.org/10.34024/rbecotur.2015.v8.6423

Pitman, T., Broomhall, S., McEwan, J., \& Majocha, E. (2010). Adult learning in educational tourism. Australian Journal of Adult Learning, 50(2), $219-238$.

Rahayu, A.S., Yani, A., \& Malik, Y. (2015). Pemanfaatan taman wisata alam Situ Gunung sebagai sumber belajar geografi SMA di kabupaten Sukabumi [Utilization of nature tourism parks Situ Gunung as a source of high school geography learning in Sukabumi district]. Antologi Geografi, 3(2), 1-9 (In Indonesian).

Reynard, E., Coratza, P., Cayla, N., Clivaz, M., Comănescu, L., Darbellay, L., Giusti, C., Grecu, F., Hobléa, F., \& Pereira, P. (2018). InterGEO: A digital platform for university education on geomorphological heritage. Geoheritage, pp: 1-13. https://doi.org/10.1007/s12371-018-0298-8

Rohani, A.H.M., \& Ahmadi, A.H. (1995). Pengelolaan Pengajaran [Teaching Management], Rineka Cipta, Jakarta.

Rudi, E., \& Fadli, N. (2012). Community of herbivory reef fishes in Northern Acehnese reef. Depik, 1(1), 37-44.

Rudi, E., Elrahimi, S.A., Kartawijaya, T., Herdiana, Y., Setiawan, F., Pardede, S.T., Campbell, S.J., \& Tamelander, J. (2009). Reef fish status in Northern Acehnese reef based on management type. Biodiversitas, 10(2), 88-93. https://doi.org/10.13057/biodiv/d100206

Russell, C.L. (1994). Ecotourism as experiential environmental education? The Journal of Experiential Education, 17(1), 16-22. https://doi.org/10.1177/ 105382599401700105

Sander, B. (2012). The Importance of education in ecotourism ventures: Lessons from Rara Avis Ecolodge, Costa Rica. Int. J. Sustainable Society, 4(4), 389-404. https://doi.org/10.1504/IJSSOC.2012.049408

Setiyono, B., Sarwono, \& Hermawan. (2012). Perencanaan pengembangan wisata alam dan pendidikan lingkungan di kawasan hutan dengan tujuan khusus (KHDTK) Cikampek [Planning for the development of natural tourism and environmental education in forest areas with special objectives (KHDTK) Cikampek]. Wacana. 15(3): 62-69 (In Indonesian).

Suhendi, A., \& Purwarno. (2018). Constructivist learning theory: The contribution to foreign language learning and teaching. The 1st Annual International Conference on Language and Literature, KnE Social Sciences \& Humanities, 87-95. https://doi.org/10.18502/kss.v3i4.1921

Utama, R.S., \& Budiyanto, A. (2017). Condition and diversity of stony corals in Sabang waters. Oceanology and limnology of Indonesia, 2(1), 69-82. https://doi.org/10.14203/oldi.2017.v2i1.25

Wanga, J.O., Patrick, O.H., Pius, O.O., \& Fredrick, Z.A.O. (2013). The nexus between environmental knowledge and ecotourism attitude among the local youths in co-educational secondary schools in Bondo Sub-County, Siaya County, Kenya. International Journal of Business and Social Research (IJBSR), 3(7), 103-116

*** Dinas Pariwisata dan Kebudayaan Kota Sabang. (2016). Form 1 daftar objek wisata 2016 [Form 1 list of attractions in 2016], DISBUDPAR Sabang City, Sabang.

***The Texas Natural Resource/Environmental Literacy Plan. (2017). What is Natural Resource/ Environmental Literacy? (Online), www.taee.org.

*** UNESCO \& UNEP. (1978). The tbilisi declaration. UNESCO/UNEP Environmental Edication Newsletter, 3(1), 13-16.

*** UNESCO. (1978). Intergovernmental conference on environmental education, Final Report, Organized by Unesco in co-operation with UNEP, Paris. 